\title{
PENGARUH PEMANFAATAN LIMBAH CAIR PABRIK KELAPA SAWIT TERHADAP KUALITAS AIR PADA LAHAN KELAPA SAWIT PT. PMP DI KABUPATEN MAYBRAT
}

\section{THE EFFECT OF USING Palm Oil Mill Effluent ON WATER QUALITY IN PALM OIL LAND PT. PMP IN MAYBRAT DISTRICT}

\author{
Kristina Daundi ${ }^{1}$, Markus Heryanto Langsa ${ }^{{ }^{*}}$, Alfhons Daniel Sirampun ${ }^{1}$ \\ ${ }^{1}$ Jurusan Kimia, FMIPA, Universitas Papua, Manokwari, 98314, Indonesia \\ Jalan Gunung Salju Amban, Manokwari \\ *email korespondensi: m.langsa@unipa.ac.id
}

\begin{abstract}
ABSTRAK
Limbah cair pabrik kelapa sawit (LCPKS) merupakan limbah yang dihasilkan dari tandan buah segar kelapa sawit. Pemanfaatkan LCPKS sebagai pupuk cair dapat membantu pertumbuhan tanaman kelapa sawit dan meningkatkan produksi tandan buah segar. Tujuan dari penelitian ini adalah untuk mengetahui karakteristik LCPKS pada kolam pematangan (maturity pond) atau kolam kontak yang akan digunakan sebagai pupuk cair di lahan perkebunan kelapa sawit dan pengaruh LCPKS terhadap kualitas air tanah dan air permukaan di kawasan perkebunan. Data sekunder (hasil analisis yang dilakukan di perkebunan kelapa sawit PT. MSIP, Kabupaten Bengkayang) digunakan sebagai pembanding dampak LCPKS setelah aplikasi. Karakterisasi LCPKS menunjukkan penurunan kadar zat pencamar yang cukup signifikan jika dibandingkan dengan rentang rata-rata kadar pencemar limbah tanpa diolah. Kadar BOD LCPKS di kolam akhir pengolahan adalah sebesar $5270 \mathrm{mg} / \mathrm{L}$ (hampir memenuhi nilai baku mutu sebesar $5000 \mathrm{mg} / \mathrm{L}$ ) dibandingkan dengan kadar rata-rata BOD tanpa pengolahan $(21280 \mathrm{mg} / \mathrm{L})$. Aplikasi LCPKS ke lahan dapat berpengaruh terhadap lingkungan yaitu berpotensi menurunkan kualitas air tanah dan air permukaan. Penurunan kualitas air ditandai dengan peningkatan nilai indeks pencemaran dan status mutu air.
\end{abstract}

Kata kunci : LCPKS, kelapa sawit, kualitas air, air tanah, air permukaan.

\section{ABSTRACT}

Palm oil mill effluent (LCPKS) is waste produced from fresh fruit bunches of oil palm. Utilization of LCPKS as liquid fertilizer can help the growth of oil palm plants and increase the production of fresh fruit bunches. The purpose of this study was to determine the characteristics of LCPKS in maturity ponds or contact ponds that will be used as liquid fertilizer in oil palm plantations and the effect of LCPKS on groundwater and surface water quality in plantation areas. Secondary data (results of analysis conducted at PT. MSIP's oil palm plantation, Bengkayang Regency) were used to compare the impact of LCPKS after application. The characterization of LCPKS showed a significant decrease in pollutant levels when compared to the average range of untreated sewage pollutant levels. The BOD level of LCPKS in the final treatment pond was $5270 \mathrm{mg} / \mathrm{L}$ (almost meeting the quality standard value of $5000 \mathrm{mg} / \mathrm{L})$ compared to the average level of BOD without treatment $(21280 \mathrm{mg} / \mathrm{L})$. The application of LCPKS to land can affect the environment, which has the potential to reduce the quality of ground water and surface water. The decline in water quality is indicated by an increase in the value of the pollution index and the status of water quality.

Keywords: LCPKS, oil palm, water quality, ground water, surface water. 


\section{PENDAHULUAN}

Kelapa sawit (Elaeis guineensis Jacq) merupakan komoditas perkebunan yang memiliki nilai ekonomis yang tinggi. Kelapa sawit berperan penting dalam peningkatan devisa negara, penyerapan tenaga kerja dan peningkatan perekonomian di Indonesia (Sembiring et al, 2015). Walaupun bukan termasuk tumbuhan endemik Indonesia (Fauzi et al, 2012), kelapa sawit dapat tumbuh subur dan berkembang dengan baik dan menjadi salah satu andalan Indonesia di sektor pengembangan industri berbasis pertanian (agroindustri).

Luas area perkebunan kelapa sawit di Indonesia menurut Kresnarini (2011) adalah seluas 290.000 ha pada tahun 1980 , kemudian meningkat menjadi 5.9 juta ha di tahun 2006. Selanjutnya menurut Indarti (2014) luas lahan kebun kelapa sawit adalah 10,01 juta ha di tahun 2013. Berdasarkan data statistik perkebunan di Indonesia komoditas sawit pada tahun 2014-2016 dari Direktorat Jenderal Perkebunan diprediksi bahwa data luas area perkebunan pada tahun 2016 akan mencapai 11.672.861 ha dengan jumlah total produksi minyak kelapa sawit 33.500.691 ton (Direktorat Jenderal Perkebunan, 2015). Luas area perkebunan kelapa sawit pada PT. PMP adalah 25.159 Ha dengan kapasitas produksi 2 x 60 Ton TBS/Jam (Keputusan Gubernur Papua Barat, 2011).

Pabrik kelapa sawit (PKS) menghasilkan tiga jenis limbah yaitu limbah padat, cair dan gas (Wahyudi et al, 2011). Limbah cair pabrik kelapa sawit (LCPKS) merupakan limbah yang paling banyak dihasilkan dari tandan buah segar kelapa sawit. Menurut Budianta (2004) dari satu tandan buah segar kelapa sawit sekitar $60 \%$ adalah LCPKS.

Proses ekstraksi minyak kelapa sawit tidak menggunakan bahan kimia, sehingga LCPKS tidak beracun, namun dapat mencemari lingkungan. LCPKS bersifat asam (pH 3.3 - 4.6), kental, berwarna kecokelatan dengan kandungan padatan, minyak dan lemak, Chemical Oxygen Demand (COD) dan Biological Oxygen Demand (BOD) tinggi
(Rahayu et al, 2014). Pengolahan LCPKS di Indonesia menggunakan sistem kolam terbuka dengan pertimbangan keekonomisan dan kemudahan pengoperasian. Secara umum sistem ini melalui empat kolam yaitu kolam lemak (fat pit), kolam pendinginan (cooling pond), kolam anaerobik (anaerobic pond) dan kolam pematangan limbah (maturity pond) akan tetapi, beberapa perusahaan seringkali menambah jumlah kolam dengan tujuan mendapatkan limbah dengan kandungan bahan pencemar yang sesuai dengan baku mutu limbah yang telah ditetapkan oleh pemerintah.

LCPKS adalah salah satu limbah utama industri kelapa sawit yang memiliki potensi mencemari lingkungan yang cukup tinggi di antara limbah pabrik lainnya. Ibe et al (2014), Hartley (2004) dan Roslan et al (2009) mengungkapkan bahwa LCPKS hasil buangan dari pabrik kelapa sawit dapat mencemari sungai dan tanah di sekitarnya. Menurut Rahayu et al (2014), LCPKS yang dibuang langsung ke sungai dapat menyebabkan kematian biota perairan sedangkan menurut Orji et al (2006) dalam penelitiannya menunjukkan bahwa LCPKS yang dibuang langsung ke tanah menyebabkan populasi mikroorganisme pada tanah menurun. Oleh karena itu perlu dilakukan pengelolaan LCPKS terlebih dahulu dan menyeluruh sehingga LCPKS hasil pengolahan yang akan dilepas ke lingkungan telah memenuhi baku mutu limbah cair yang dipersyaratkan.

Regulasi memungkinkan pengusaha kelapa sawit untuk memanfaatkan LCPKS sebagai pupuk cair untuk membantu pertumbuhan tanaman kelapa sawit dan meningkatkan produksi tandan buah segar. Pemanfaatan LCPKS di lahan perkebunan kelapa sawit harus melalui kajian yang mendalam terutama dampak LCPKS terhadap komponen lingkungan, baik air, tanah dan udara (Peraturan Menteri Negara Lingkungan Hidup, 2003). Khusus komponen air baik air permukaan (sungai) maupun air tanah, kajian pemanfaatan LCPKS dilakukan untuk memastikan bahwa LCPKS yang diaplikasikan kelahan tidak menyebabkan terjadinya pencemaran badan air yang berada di sekitar lahan aplikasi LCPKS. Penelitian ini dilakukan untuk mengetahui ada tidaknya pengaruh 
pemanfaatan LCPKS pada air permukaan (sungai) dan air tanah (sumur pantau) di lahan aplikasi dengan membandingkan kualitas (status mutu air) sebelum dan setelah LCPKS diaplikasikan kelahan perkebunan kelapa sawit.

Penelitian ini bertujuan untuk mengetahui pengaruh limbah pabrik kelapa sawit terhadap kualitas air permukaan/bawah tanah yang dicapai melalui:

a. Karakterisasi sifat fisika dan kimia limbah cair olahan pabrik kelapa sawit (LCPKS) pada kolam pematangan (maturity pond) atau kolam kontak yang akan digunakan sebagai pupuk cair di aplikasi lahan perkebunan kelapa sawit.

b. Perubahan status mutu air sebelum dan setelah aplikasi LCPKS pada lahan perkebunan kelapa sawit.

\section{METODE PENELITIAN}

\section{Pengambilan Sampel Air Limbah}

Pengambilan sampel LCPKS dilakukan di kolam pematangan (maturity pond) atau kolam kontak dan lahan perkebunan kelapa sawit milik PT. Putera Manunggal Perkasa (PMP) di Kabupaten Maybrat.

Prosedur pengambilan sampel mengacu pada metoda Berdasarkan SNI 6989.59:2008. Tentang metoda pengambilan contoh air limbah, yaitu dengan cara mengambil sampel pada kolam pematangangan dengan ukuran

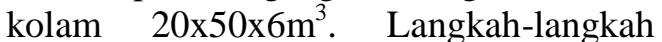
pengambilan sampel adalah bilas alat dengan sampel yang akan diambil, sebanyak 3 (tiga) kali kemudian ambil sampel sesuai dengan peruntukan analisis dan campurkan dalam penampung sementara, kemudian homogenkan dan masukkan ke dalam wadah yang sesuai peruntukan analisis.

Alat yang digunakan untuk pengambilan sampel terbuat dari bahan yang tidak mempengaruhi sifat sampel, mudah dicuci dari bekas sampel sebelumnya, sampel mudah dipindahkan ke dalam botol penampung tanpa ada sisa bahan tersuspensi di dalamnya, mudah dan aman untuk dibawa.

\section{Pengambilan Sampel Air}

Pengambilan sampel air pada penelitian ini dilakukan untuk mengetahui kondisi kualitas air. Penentuan titik pengambilan sampel dilakukan berdasarkan SNI 6989.57:2008. Tentang metoda pengambilan contoh air permukaan. Pengambilan sampel air permukaan didasarkan atas debit/laju alir air sungai, jarak/panjang, lebar dan kedalaman sungai sehingga sampel air yang diambil merata pada semua bagian sungai dan SNI 6989.58:2008. Tentang metoda pengambilan contoh air tanah. Pengambilan sampel air tanah harus memperhatikan pola arah aliran air tanah, dapat berasal dari air tanah bebas (tak tertekan) seperi sumur gali dan air tanah tertekan seperti sumur bor.

\section{Karakterisasi Sampel Air Limbah}

Beberapa parameter untuk menguji karakteristik sampel air limbah (LCPKS) mengacu pada Lampiran A.IV Keputusan Menteri Negara Lingkungan Hidup No. 51 Tahun 1995 tentang Baku Mutu Limbah Cair Bagi Kegiatan Industri khusus industri kelapa sawit. Parameter tersebut diantaranya $\mathrm{pH}$, BOD, COD, Minyak dan Lemak.

Nilai $\mathrm{pH}$ sampel air limbah dan air permukaan diukur menggunakan alat $\mathrm{pH}$ meter yang mengacu pada metoda SNI 06-6989.112004. Pertama -tama electrode dikeringkan dengan kertas tisu selanjutnya dibilas dengan aquades. Kemudian bilas elektroda menggunakan sampel yang akan diuji. Selanjutnya celupkan elektoda kedalam sampel uji sampai $\mathrm{pH}$ meter menujukkan pembacaan yang tepat.

Kadar $\mathrm{BOD}_{5}$ diukur menggunakan SNI 6989-72-2009. Sejumlah sampel uji ditambahkan kedalam larutan pengencer jenuh oksigen yang telah ditambahkan larutan nutrisi dan bibit mikroba, kemudian diinkubasi dalam ruang gelap pada suhu $20^{\circ} \mathrm{C} \pm 1^{\circ} \mathrm{C}$ selama 5 hari. Nilai BOD dihitung berdasarkan selisih konsentrasi oksigen terlarut 0 hari dan 5 hari. Bahan kontrol standar dalam uji BOD ini adalah larutan glukosa-asam glutamat.

Kadar COD diukur dengan refluks terbuka secara titrimetri yang mengacu pada metoda SNI 06-6989.15-2004. Sampel uji dioksidasi dengan campuran mendidih asam 
sulfat dan kalium dikromat yangdiketahui normalitasnya dalam suatu refluk selama 2 jam. Kelebihan kalium dikromat yangtidak tereduksi, dititrasi dengan larutan ferro ammonium sulfat (FAS) dan dihitung untuk mengetahui kadar COD nya.

Kadar Minyak dan lemak diukur secara gravimetri yang mengacu pada metode SNI 06-6989.10-2004. Minyak dan lemak dalam sampel uji air diekstraksi dengan pelarut organik dalam corong pisah dan untuk menghilangkan air yang masih tersisa digunakan $\mathrm{Na}_{2} \mathrm{SO}_{4}$ anhidrat. Ekstrak minyak dan lemak dipisahkan dari pelarut organik secara destilasi. Residu yang tertinggal pada labu destilasi ditimbang sebagai minyak dan lemak.

\section{Karakterisasi Sampel Air}

Beberapa parameter untuk menguji karakterisasi sampel air mengacu pada parameter kualitas air permukaan untuk air Kelas 2 sedangkan parameter kualitas air tanah/sumur mengikuti air Kelas 1 menurut Peraturan Pemerintah No. 82 tahun 2001 tentang pengelolaan kualitas air dan pengendalian pencemaran air. Parameter tersebut diantaranya TDS, TSS, Kekeruhan, DO, Nitrat dan Amonia.

Kadar TDS diukur secara gravimetri yang mengacu pada SNI 06-6989.27-2005. Langkah-langkah dalam pengujian TDS yaitu kocok contoh uji sampai homogen, pipet $50 \mathrm{ml}$ sampai $100 \mathrm{ml}$ contoh uji, masukkan kedalam alat penyaring yang telah dilengkapi dengan alat pompapenghisap dan kertas saring. Kemudian operasikan alat penyaringnya. Setelah contoh tersaring semuanya bilas kertas saring dengan air suling sebanyak $10 \mathrm{ml}$ dan dilakukan 3 kali pembilasan. Lanjutkan penghisapan selama kira-kira 3 menit setelah penyaringan sempurna. Kemudian pindahkan seluruh hasil saringan termasuk air bilasan kedalam cawan yang telah mempunyai berat tetap. Uapkan hasil saringan yang ada dalam cawan sehingga kering pada penangas air. Setelah itu masukkan cawan yang berisi padatan terlarut yang sudah kering ke dalam oven pada suhu $180^{\circ} \mathrm{C} \pm 2^{\circ} \mathrm{C}$ selama tidak kurang dari 1 jam. Pindahkan cawan dari oven dengan penjepit dan dinginkan dalam deksikator, setelah dingin segera timbang dengan neraca analitik. Ulangi langkah pengeringan, pendingian dan timbang sehingga diperoleh berat tetap (catat sebagai B gram).

Nilai kekeruhan diukur menggunakan nefelometer yang mengacu pada SNI 066989.25-2005. Langkah-langkah dalam pengujian kekeruhan hal pertama yang dilakukan adalah kalibrasi nefelometer dengan mengoptimalkan nefelometer untuk pengujian kekeruhan, sesuai petunjuk penggunaan alat. Masukkan suspensi baku kekeruhan (misalnya 40 NTU) ke dalam tabung pada nefelometer kemudian pasang tutupnya. Biarkan alat menunjukkan nilai pembacaan yang stabil. Kemudian atur alat sehingga menunjukkan angka kekeruhan larutan baku. Selanjutnya dilakukan penetapan contoh uji, yaitu dengan cuci tabung nefelometer dengan air suling, kocok contoh dan masukkan contoh ke dalam tabung pada nefelometer dan pasang tutupnya. Biarkan alat menunjukkan nilai pembacaan yang stabil. Kemudian catat nilai kekeruhan contoh yang teramati.

Kadar DO diukur secara yodometri (Modifikasi azida) yang mengacu pada SNI 06-6989.14-2004. Langkah-langkah dalam pengujian DO yaitu siapkan sampel kemudian tambahkan $1 \mathrm{~mL} \mathrm{MnSO}_{4}$ dan $1 \mathrm{~mL}$ alkali azida dengan ujung pipet tepat diatas permukaan larutan, tutup segera dan homogenkan hingga terbentuk gumpalan sempurna. Biarkan gumpalan mengendap 5-10 menit, kemudian tambahkan $1 \mathrm{~mL} \mathrm{H}_{2} \mathrm{SO}_{4}$ pekat, tutup dan homogenkan higga endapan larut sempurna, pipet sebanyak $50 \mathrm{~mL}$ masukkan kedalam erlenmeyer $150 \mathrm{~mL}$. Kemudian titrasi dengan $\mathrm{Na}_{2} \mathrm{~S}_{2} \mathrm{O}_{3}$ dengan indikator amilum/kanji sampai warna biru tepat hilang.

Kadar Amonia diukur dengan metoda indofenol menggunakan spektrofotometer yang mengacu pada metoda SNI 19-7119.12005. Larutan sampel dimasukkan kedalam tabung uji $25 \mathrm{~mL}$, kemudian tambahkan $2 \mathrm{~mL}$ larutan penyangga, $5 \mathrm{~mL}$ larutan pereaksi fenol dan 2,5 mL larutan pereaksi natrium hipoklorit lalu homogenkan. Masukkan larutan tersebut kedalam kuvet pada alat spektrofotometer, lalu ukur serapannya pada panjang gelombang $630 \mathrm{~nm}$.Setelah serapan sampel terbaca, kemudia menghitung jumlah NH3yang diperoleh dari kurva kalibrasi.

Kadar Nitrat diukur dengan spektrofotometer UV-visibel secara reduksi kadmium yang mengacu pada metoda SNI 
6989.79:2011. Senyawa nitrat dalam contoh uji direduksi menjadi nitrit oleh kadmium $(\mathrm{Cd})$ yang dilapisi dengan tembaga $(\mathrm{Cu})$ dalam suatu kolom. Nitrit total yang terbentuk bereaksi dengan sulfanilamid dalam suasana asam menghasilkan senyawa diazonium. Senyawa diazonium kemudian bereaksi dengan $\quad \mathrm{N}$-(1-naphthyl)-ethylenediamine dihydrochloride (NED) yang berwarna merah muda. Senyawa azo ini ekivalen dengan senyawa diazonium yang ekivalen dengan nitrit total. Warna merah diukur absorbansinya dengan spektrofotometer pada panjang gelombang disekitar $543 \mathrm{~nm}$.

\section{Penentuan Status Mutu Air}

Penentuan status mutu air dilakukan dengan metoda indeks pencemaran (IP) menurut Sumiotomo dan Nerow (1970) dalam Lampiran II-Keputusan Menteri Negara Lingkungan Hidup Nomor 51 Tahun 2004 tentang Pedoman Penentuan Status Mutu Air. Nilai IP suatu sampel air dihitung menggaunakan persamaan berikut:

$$
P I_{j}=\sqrt{\frac{\left(C_{i} / L_{i j}\right)_{M}^{2}+\left(C_{i} / L_{i j}\right)_{R}^{2}}{2}}
$$

Dimana:

$\mathrm{L}_{\mathrm{i}}$ : Konsentrasi parameter kualitas air dalam baku mutu peruntukan air (j)

$\mathrm{C}_{\mathrm{i}}$ : Konsentrasi parameter kualitas air hasilsurvei

$\mathrm{PI}_{\mathrm{j}}$ : Indeks pencemaran bagi peruntukan ( $\mathrm{j}$ )

(Ci/Lij) M : Nilai Ci/LijMaksimum

(Ci/Lij) R : Nilai Ci/Lij Rata-rata

Adapun hubungan tingkat ketercemaran dengan criteria indeks pencemaran berdasarkan Keputusan Menteri Negara Lingkungan Hidup Nomor 115 Tahun 2003 tentang Penetapan Status Mutu Air sebagai berikut :

1. $0 \leq \mathrm{PIj} \leq 1,0$ : Memenuhi baku mutu (kondisi baik)

2. $1,0<\mathrm{PIj}<5,0$ : Cemar ringan

3. $5,0<\mathrm{PIj} \leq 10$ : Cemar sedang

4. $\operatorname{PIj}>10 \quad$ : Cemar berat

Perubahan nilai IP sampel air sebelum dan setelah pemanfaatan LCPKS menunjukkan pengaruh LCPKS terhadap kualitas air.

\section{HASIL DAN PEMBAHASAN}

Penelitian tentang pengaruh pemanfaatan limbah cair pabrik kelapa sawit terhadap kualitas air dilakukan dengan menganalisis kualitas air limbah pabrik kelapa sawit dan kualitas air sungai. Pada data analisis digunakan data primer (Hasil analisis yang dilakukan pada lahan kelapa sawit PT.PMP, kabupaten Maybrat sebelum aplikasi LCPKS) dan data sekunder (Hasil analisis yang dilakukan pada lahan kelapa sawit PT.Mitra Inti Sejati Plantation (PT.MISP) Kabupaten Bengkayang, Setelah aplikasi LCPKS). Penggunaan data sekunder ini hanya sebagai pembanding untuk mengetahui dampak aplikasi LCPKS di lahan kelapa sawit dikarenakan hingga laporan ini dibuat fasilitas utama dan penunjang aplikasi LCPKS di lapangan belum selesai. Hal ini berdampak pada penundaan rencana aplikasi LCPKS ke lahan dari jadwal semula.

\section{Lokasi Pengambilan Sampel}

Penelitian dilakukan pada 3 titik air permukaan dan 2 titik air sumur pantau. Penentuan titik pengambilan sampel dipilih karena lokasi ini dekat dengan IPAL dan lahan aplikasi LCPKS kelapa sawit.

Tabel 1. Titik koordinat pengambilan sampel

\begin{tabular}{|c|c|}
\hline Sampel & Titik Koordinat \\
\hline \begin{tabular}{lll} 
Air & \multicolumn{2}{c}{ Permukaan } \\
Sungai & Kais & Hilir \\
(AP1) & &
\end{tabular} & $\begin{array}{l}\text { S } 01^{\circ} 49^{\prime} \quad 15,7^{\prime \prime} \\
\text { E } 132^{\circ} 27^{\prime} 34,0^{\prime \prime}\end{array}$ \\
\hline $\begin{array}{l}\text { Air } \\
\text { Sungai } \\
\text { (AP2) }\end{array}$ & 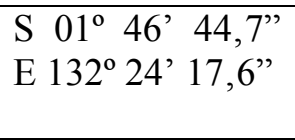 \\
\hline $\begin{array}{lr}\text { Air } & \text { Permukaan } \\
\text { Sungai } & \text { Safirin Hilir } \\
\text { (AP3) } & \end{array}$ & 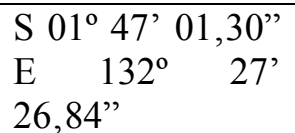 \\
\hline $\begin{array}{l}\text { Sumur Pantau Block } \\
\text { F11 (SP1) }\end{array}$ & $\begin{array}{l}\mathrm{S} \quad 01^{\circ} \quad 4^{\prime} \\
25,146^{\prime \prime} \mathrm{E} \\
27,172^{\circ} \\
27,973^{\prime \prime}\end{array}$ \\
\hline $\begin{array}{l}\text { Sumur Pantau Block } \\
\text { F12 (SP2) }\end{array}$ & 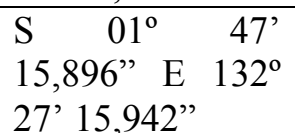 \\
\hline
\end{tabular}




\section{Karakterisasi Sampel Air Limbah}

Karakterisasi sampel air limbah dilakukan dengan tujuan agar dapat mengetahui konsentrasi dari parameter fisika dan kimia dalam air limbah. Hasil karakterisasi sampel air limbah dapat dilihat pada Tabel 2.

Tabel 2. Hasil Karakterisasi Sampel Air Limbah

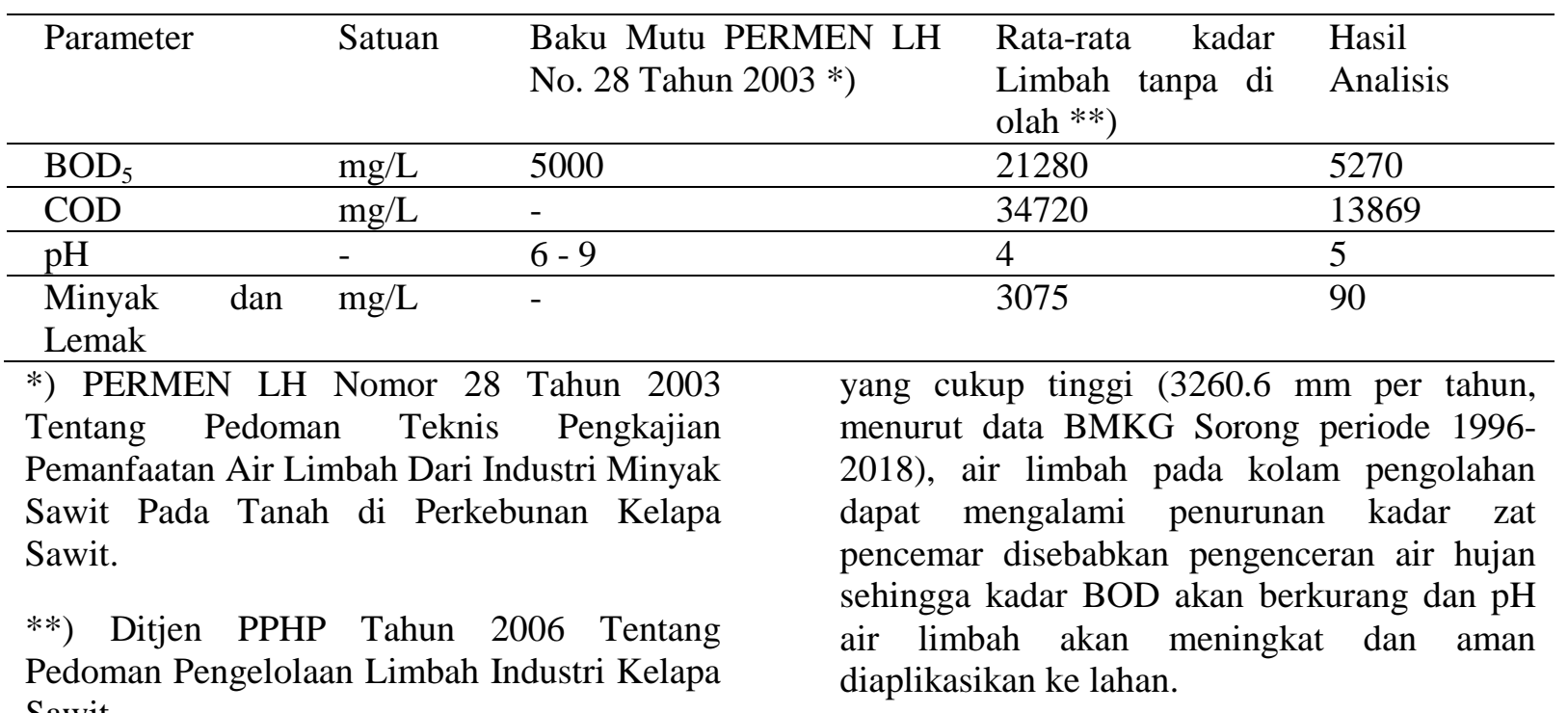

Berdasarkan hasil analisis pada Tabel 2 dapat dilihat bahwa kualitas LCPKS mengalami penurunan yang cukup signifikan jika dibandingkan dengan rentang rata-rata kadar pencemar limbah tanpa diolah. Meskipun hasil yang didapat masih belum memenuhi baku mutu yang ditetapkan oleh PERMENLH No. 28 Tahun 2003 tentang pedoman teknis pengkajian pemanfaatan air limbah dari industri minyak sawit pada tanah di perkebunan kelapa sawit tetapi dengan kondisi lingkungan yang memiliki curah hujan

\section{Karakterisasi Sampel Air Permukaan}

Karakterisasi sampel air permukaan bertujuan agar dapat mengetahui konsentrasi dari parameter fisika dan kimia dalam air. Hasil karakterisasi sampel air permukaan sebelum aplikasi LCPKS dan sesudah aplikasi LCPKS dapat dilihat pada Tabel 3 dan Tabel 4.

a. Sebelum Aplikasi LCPKS

Tabel 3. Hasil karakterisasi air permukaan sebelum aplikasi LCPKS

\begin{tabular}{lccccc}
\hline \multirow{2}{*}{ Parameter } & Satuan & Baku mutu*) & \multicolumn{3}{c}{ Hasil Analisis } \\
\cline { 3 - 6 } & & & AP1 & AP2 & AP3 \\
\hline TDS & $\mathrm{mg} / \mathrm{L}$ & 1000 & 112 & 92 & 103 \\
\hline TSS & $\mathrm{mg} / \mathrm{L}$ & 50 & 5 & 16 & 7 \\
\hline $\mathrm{pH}$ & - & $6-9$ & 7,9 & 7,7 & 8 \\
\hline BOD & $\mathrm{mg} / \mathrm{L}$ & 3 & 3 & 5 & 4 \\
\hline COD & $\mathrm{mg} / \mathrm{L}$ & 25 & 16 & 20 & 18 \\
\hline DO & $\mathrm{mg} / \mathrm{L}$ & 4 & 5,1 & 4,6 & 4,9 \\
\hline Nitrat & $\mathrm{mg} / \mathrm{L}$ & 10 & 0,06 & 0,06 & $<0,05$ \\
\hline
\end{tabular}

Sumber : PT. Global Quality Analitical (2020); Hasil karakterisasi air permukaan di PT. PMP, Oktober 2020

Keterangan : *)Peraturan Pemerintah Republik Indonesia No.82 Tahun 2001 Tentang Pengolahan Kualitas Dan Air Pengendalian Pencemaran Air Presiden Republik Indonesia. Air 
kelas 2 yang peruntukannya dapat digunakan untuk prasarana/sarana rekreasi air, pembudidayaan ikan air tawar, peternakan, air untuk mengairi pertanaman, dan atau peruntukan lain yang mempersyaratkan mutu air yang sama dengan kegunaan tersebut.

AP1 = Sungai Kais Hilir, AP2 = Sungai Haman Hilir, AP3 = Sungai Safirin Hilir

Berdasarkan hasil analisis pada Tabel 3 terdapat dua sampel yang mempunyai nilai BOD yang melebihi nilai baku mutu yaitu pada sampel AP2 dan AP3, sementara kadar COD kedua sampel air ini masih di bawah baku mutu. Hal ini menunjukkan bahwa senyawa organic pada sampel air lebih bersifat mudah terurai/degradasi (biodegradable) oleh mikroorganisme. Sedangkan dari ketiga sampel yang dianalisis memiliki nilai DO yang melebihi batas minimum yaitu $4 \mathrm{mg} / \mathrm{L}$.

b. Setelah Aplikasi LCPKS

Tabel 4. Hasil karakterisasi air permukaan sesudah aplikasi LCPKS

\begin{tabular}{lcccc}
\hline \multirow{2}{*}{ Parameter } & Satuan & Baku mutu*) & \multicolumn{2}{c}{ Hasil Analisis } \\
\cline { 3 - 5 } & & & APRF1 & APRF2 \\
\hline BOD & $\mathrm{mg} / \mathrm{L}$ & 3 & 24 & 84,5 \\
\hline TSS & $\mathrm{mg} / \mathrm{L}$ & 50 & 6,56 & 24 \\
\hline $\mathrm{pH}$ & - & $6-9$ & 4,32 & 6,5 \\
\hline DO & $\mathrm{mg} / \mathrm{L}$ & 4 & 1,44 & 0,64 \\
\hline Amonia & $\mathrm{mg} / \mathrm{L}$ & $\leq 0,02$ & &
\end{tabular}

Sumber : PT. Sucofindo, 2014

Keterangan : *)Peraturan Pemerintah Republik Indonesia No.82 Tahun 2001 Tentang Pengolahan Kualitas Dan Air Pengendalian Pencemaran Air Presiden Republik Indonesia. Air kelas 2 yang peruntukannya dapat digunakan untuk prasarana/sarana rekreasi air, pembudidayaan ikan air tawar, peternakan, air untuk mengairi pertanaman, dan atau peruntukan lain yang mempersyaratkan mutu air yang sama dengan kegunaan tersebut.

APRF1 = Air permukaan referensi 1 (Hulu sungai), APRF2 = Air permukaan referensi 2 (Hilir sungai)

Berdasarkan hasil analisis kedua sampel pada Tabel 4 mempunyai nilai BOD yang melebihi baku mutu dengan kadar 84,5 $\mathrm{mg} / \mathrm{L}$ pada titik APRF2 lebih tinggi daripada titik APRF1 dengan kadar $24 \mathrm{mg} / \mathrm{L}$, sedangkan untuk nilai TSS dan DO hanya pada titik APRF1 yang melebihi baku mutu yaitu 156 $\mathrm{mg} / \mathrm{L}$ dan $4,32 \mathrm{mg} / \mathrm{L}$.

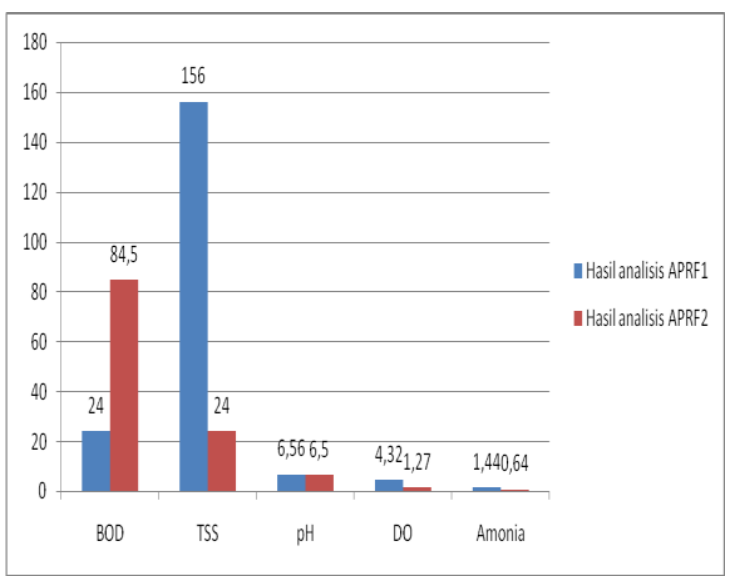

Gambar 1. Grafik karakteristik air permukaan

APRF1 adalah data air permukaan referensi 1 yang merupakan data analisis sampel yang diambil pada hulu sungai. Data dari hulu sungai ini dianggap sebagai data rona awal karena bagian hulu sungai berada di atas 
sehingga tidak terdampak langsung dengan aplikasi LCPKS ke lahan. Sedangkan, untuk APRF2 adalah data air pemukaan referensi 2 yang merupakan data analasis sampel yang diambil pada hilir sungai. Data dari hilir sungai ini dianggap sebagai hasil/dampak dari aplikasi LCPKS ke lahan kerena bagian hilir sungai memiliki lokasi yang dekat dengan lokasi aplikasi LCPKS ke lahan.

Berdasarkan Gambar 1 dapat dilihat bahwa nilai BOD pada bagian hulu sungai yang tidak terkena dampak langsung LCPKS adalah $24 \mathrm{mg} / \mathrm{L}$ sedangkan pada bagian hilir sungai yang terkena dampak langsung dari aplikasi LCPKS adalah sebesar $84,5 \mathrm{mg} / \mathrm{L}$ sehingga aplikasi LCPKS ke lahan dapat meningkatkan kadar BOD pada air permukaan. Sedangkan untuk parameter Amonia dan TSS kadarnya lebih tinggi pada bagian hulu dibandingkan dengan hilir sungai referensi. Hal ini kemungkinan disebabkan tingginya proses degradasi/penguraian material yang kaya nitrogen organik (misalnya daun, ranting atau akar tumbuhan) di bagian hulu sungai (virgianti dkk, 2014).

\section{Karakterisasi Sampel Air Tanah}

Sampel air tanah dianalisis dengan tujuan untuk mengetahui konsentrasi dari parameter fisika dan kimia yang terkandung didalamnya. Hasil analisis sampel air tanah sebelum dan sesudah aplikasi LCPKS dapat dilihat pada Tabel 5 dan Tabel 6.

\section{a. Sebelum aplikasi LCPKS}

Tabel 5. Hasil karakterisasi air tanah sebelum aplikasi LCPKS

\begin{tabular}{lcccc}
\hline Parameter & $\begin{array}{c}\text { Baku } \\
\text { mutu* }\end{array}$ & Satuan & \multicolumn{2}{c}{ Hasil Analisis } \\
\cline { 3 - 5 } & 1500 & $\mathrm{mg} / \mathrm{L}$ & $\mathrm{SP} 1$ & $\mathrm{SP} 2$ \\
\hline TDS & $6,5-$ & - & 5,37 & 41 \\
\hline $\mathrm{pH}$ & & & & Satuan \\
\hline
\end{tabular}

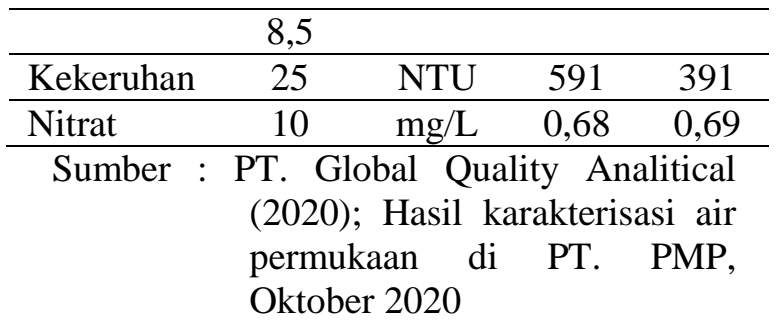

Keterangan : *)PERMENKES RI Nomor 32 Tahun 2017 tentang standar baku mutu kesehatan lingkungan dan persyaratan kesehatan air untuk keperluan higiene sanitasi, kolam renang, solus per aqua, dan pemandian umum.

$$
\begin{aligned}
& \text { SP1 = Air tanah } \\
& \text { pada lahan } \\
& \text { kontrol, SP2 = } \\
& \text { Air tanah pada } \\
& \text { lahan lahan } \\
& \text { aplikasi. }
\end{aligned}
$$

Berdasarkan hasil analisis pada Tabel 5 dapat diketahui bahwa kualitas air tanah sebelum aplikasi di PT. PMP pada lahan control (SP1) dan lahan aplikasi (SP2) memenuhi baku mutu yang ditetapkan oleh PERMENKES RI Nomor 32 Tahun 2017 Kecuali untuk parameter kekeruhan yaitu pada lahan control (SP1) adalah sebesar 591 dan lahan aplikasi (SP2) adalah sebesar 391 NTU.

\section{b. Sesudah aplikasi LCPKS}

Berikut adalah hasil karakterisasi sampel air tanah pada lahan aplikasi dan lahan kontrol

\begin{tabular}{|c|c|c|c|c|c|c|}
\hline \multirow[t]{2}{*}{ Parameter } & \multirow{2}{*}{$\begin{array}{c}\text { Baku } \\
\text { mutu*) }\end{array}$} & \multirow[t]{2}{*}{ Satuan } & \multicolumn{4}{|c|}{ Hasil Analisis } \\
\hline & & & ATK1 & ATK2 & ATA1 & ATA2 \\
\hline TSS & 50 & $\mathrm{mg} / \mathrm{L}$ & 60 & 120 & 126 & 342 \\
\hline BOD & 3 & $\mathrm{mg} / \mathrm{L}$ & 25,67 & 18 & 41 & 30 \\
\hline $\mathrm{pH}$ & $6-9$ & - & 6,94 & 6,92 & 7,02 & 6,9 \\
\hline Amonia & $\leq 0,02$ & $\mathrm{mg} / \mathrm{L}$ & 5,3 & 5 & 6,43 & 5,78 \\
\hline \multicolumn{4}{|c|}{ Sumber : PT. Sucofindo, 2014} & baku & mutu & kesehatan \\
\hline \multicolumn{4}{|c|}{$\begin{array}{c}\text { Keterangan : *)PERMENKES RI Nomor } 32 \\
\text { Tahun } 2017 \text { tentang standar }\end{array}$} & \multicolumn{3}{|c|}{$\begin{array}{l}\text { lingkungan dan persyaratan } \\
\text { kesehatan air untuk keperluan } \\
\text { higiene sanitasi, kolam renang, }\end{array}$} \\
\hline
\end{tabular}
sesudah aplikasi LCPKS disajikan dalam Tabel 6.

Tabel 6. Hasil karakterisasi air tanah sesudah aplikasi pada lahan aplikasi dan lahan kontrol 
solus per aqua, dan pemandian umum.

ATK1 = Air tanah pada lahan kontrol 1, ATK2 = Air tanah pada lahan kontrol 2, ATA1 = Air tanah pada lahan aplikasi 1, ATA2 = Air tanah pada lahan aplikasi 2.

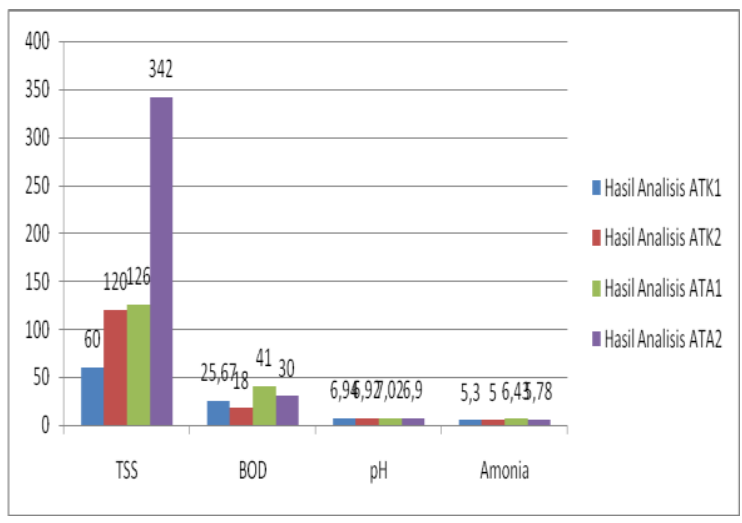

Gambar 2. Grafik karakterisasi air tanah

Berdasarkan Gambar 2, Sebagian besar parameter kualitas air pada lahan kontrol sudah menunjukkan tercemarnya air tanah di kawasan tersebut, namun nilainya masih di bawah pencemaran yang terjadi di lahan aplikasi. Artinya aplikasi LCPKS ke lahan dapat meningkatkan pencemaran air tanah disekitar lahan aplikasi LCPKS. Pencemaran yang terjadi di lahan kontrol disebabkan karena adanya faktor pemupukan yang berkontribusi dalam pemasukan bahan organik ke dalam air tanah, tidak adanya pengenceran oleh air hujan juga menjadi salah satu faktor yang memperparah pencemaran di lahan kontrol ini. Sedangkan pada lahan aplikasi, proses pengaliran limbah pada lahan telah mengakibatkan pencemaran dengan adanya bahan organik yang terdapat pada LCPKS. Pada Lahan aplikasi bahan pencemar secara langsung masuk ke dalam air tanah melalui media tanah. Maka dari itu lahan aplikasi mempunyai pengaruh terhadap kualitas air tanah.

Dampak aplikasi LCPKS terhadap kualitas air pada lahan perkebunan kelapa sawit PT. Mitra Inti Sejati Plantation (PT.MISP) Kabupaten Bengkayang diperkirakan akan sama dengan kualitas air pada lahan perkebunan kelapa sawit milik PT. PMP
Kabupatem Maybrat. Dampak yang terjadi berupa peningkatan pencemaran yang terjadi pada air permukaan dan peningkatan kadar TSS, BOD dan Amonia yang terjadi pada air tanah (lahan kontrol dan lahan aplikasi). Namun, dengan adanya perbedaan topografi dan curah hujan pada lokasi, tingkat pencemaran yang terjadi pada PT. PMP kemungkinan tidak akan sebesar yang terjadi di PT. MISP.

\section{Analisis Status Mutu Air}

Status mutu air menunjukan tingkat pencemaran suatu sumber air dalam waktu tertentu, dibandingkan dengan baku mutu air yang ditetapkan. Sungai dikatakan tercemar apabila tidak dapat digunakan sesuai dengan peruntukaannya secara normal (Azwir,2006). Dalam penelitian ini parameter yang digunakan dalam menganalisis status mutu air adalah pH, TSS, DO, BOD, COD, TDS, Nitrat, Kekeruhan dan Amonia yang dibandingkan dengan kriteria mutu air kelas II. Analisis status mutu air dilakukan berdasarkan pada pedoman penentuan status mutu air yang ditetapkan oleh Kementerian lingkungan hidup nomor 115 tahun 2003 dengan mengunakan Indeks Pencemaran (IP). Metode indeks pencemaran (IP) yaitu membandingkan nilai setiap parameter dengan baku mutunya, sehingga nilai status mutu air dapat ditentukan berdasarkan perhitungan menggunakan persamaan :

$$
P I_{j}=\sqrt{\frac{\left(C_{i} / L_{i j}\right)_{M}^{2}+\left(C_{i} / L_{i j}\right)_{R}^{2}}{2}}
$$

Hasil perhitungan IP disajikan pada lampiran. Hasil rekapan IP disajikan pada Tabel 7.

Tabel 7. Hasil rekapan IP status mutu air

\begin{tabular}{ccccc}
\hline Parameter & $\mathrm{Ci}$ & $\mathrm{Li}$ & $\mathrm{Ci} / \mathrm{Li}$ & $\mathrm{Ci} / \mathrm{Li}_{\text {baru }}$ \\
\hline & & $\mathrm{AP} 1$ & & \\
\hline TDS & 112 & 1000 & 0,11 & 0,11 \\
\hline TSS & 5 & 50 & 0,1 & 0,1 \\
\hline pH & 7,9 & $6-9$ & 0,27 & 0,27 \\
\hline BOD & 3 & 3 & 1 & 1 \\
\hline COD & 16 & 25 & 0,64 & 0,64 \\
\hline DO & 5,1 & 4 & 1,27 & 1,52 \\
\hline Nitrat & 0,06 & 10 & 0,006 & 0,006 \\
\hline
\end{tabular}




\begin{tabular}{|c|c|c|c|c|}
\hline \multicolumn{5}{|c|}{ AP2 } \\
\hline TDS & 92 & 1000 & 0,09 & 0,09 \\
\hline TSS & 16 & 50 & 0,32 & 0,32 \\
\hline $\mathrm{pH}$ & 7,7 & $6-9$ & 0,13 & 0,13 \\
\hline BOD & 5 & 3 & 1,6 & 2,02 \\
\hline COD & 20 & 25 & 0,8 & 0,8 \\
\hline DO & 4,6 & 4 & 1,15 & 1,30 \\
\hline Nitrat & 0,06 & 10 & 0,006 & 0,006 \\
\hline \multicolumn{5}{|c|}{ AP3 } \\
\hline TDS & 103 & 1000 & 0,10 & 0,10 \\
\hline TSS & 7 & 50 & 0,14 & 0,14 \\
\hline $\mathrm{pH}$ & 8 & $6-9$ & 0,33 & 0,33 \\
\hline BOD & 4 & 3 & 1,3 & 1,57 \\
\hline COD & 18 & 25 & 0,72 & 0,72 \\
\hline DO & 4,9 & 4 & 1,23 & 1,45 \\
\hline Nitrat & $\begin{array}{c}< \\
0,05\end{array}$ & 10 & 0,005 & 0,005 \\
\hline \multicolumn{5}{|c|}{ APRF1 } \\
\hline TSS & 156 & 50 & 3,12 & 3,47 \\
\hline BOD & 24 & 3 & 8 & 5,51 \\
\hline DO & 4,32 & 4 & 1,08 & 1,17 \\
\hline $\mathrm{pH}$ & 6,56 & $6-9$ & 0,63 & 0,63 \\
\hline Amonia & 1,44 & $\begin{array}{c}\leq \\
0,02\end{array}$ & 72 & 10,29 \\
\hline \multicolumn{5}{|c|}{ APRF2 } \\
\hline TSS & 24 & 50 & 0,48 & 0,48 \\
\hline $\mathrm{BOD}$ & 84,5 & 3 & 28,16 & 8,25 \\
\hline DO & 1,27 & 4 & 0,32 & 0,32 \\
\hline $\mathrm{pH}$ & 6,5 & 6-9 & 0,67 & 0,67 \\
\hline Amonia & 0,64 & $\begin{array}{c}\leq \\
0,02\end{array}$ & 32 & 8,52 \\
\hline \multicolumn{5}{|c|}{ SP1 } \\
\hline TDS & 29 & 1000 & 0,03 & 0,03 \\
\hline $\mathrm{pH}$ & 5,37 & $6-9$ & 1,42 & 1,76 \\
\hline Kekeruhan & 591 & 25 & 23,64 & 7,87 \\
\hline Nitrat & 0,68 & 10 & 0,07 & 0,07 \\
\hline \multicolumn{5}{|c|}{ SP2 } \\
\hline TDS & 41 & 1000 & 0,04 & 0,04 \\
\hline
\end{tabular}

\begin{tabular}{|c|c|c|c|c|}
\hline $\mathrm{pH}$ & 7,81 & $6-9$ & 0,21 & 0,21 \\
\hline Kekeruhan & 391 & 25 & 15,64 & 6,97 \\
\hline Nitrat & 0,69 & 10 & 0,07 & 0,07 \\
\hline \multicolumn{5}{|c|}{ ATK1 } \\
\hline TSS & 60 & 50 & 1,2 & 1,4 \\
\hline BOD & 25,67 & 3 & 8,6 & 5,7 \\
\hline $\mathrm{pH}$ & 6,94 & $6-9$ & 0,37 & 0,37 \\
\hline Amonia & 5,3 & $\begin{array}{c}\leq \\
0,02\end{array}$ & 265 & 13,12 \\
\hline \multicolumn{5}{|c|}{ ATK2 } \\
\hline TSS & 120 & 50 & 2,4 & 2,90 \\
\hline BOD & 18 & 3 & 6 & 4,90 \\
\hline $\mathrm{pH}$ & 6,92 & $6-9$ & 0,39 & 0,39 \\
\hline Amonia & 5 & $\begin{array}{c}\leq \\
0,02\end{array}$ & 250 & 13 \\
\hline \multicolumn{5}{|c|}{ ATA1 } \\
\hline TSS & 126 & 50 & 2,52 & 3 \\
\hline BOD & 41 & 3 & 13,67 & 6,68 \\
\hline $\mathrm{pH}$ & 7,02 & $6-9$ & 0,32 & 0,32 \\
\hline Amonia & 6,43 & $\begin{array}{c}\leq \\
0,02\end{array}$ & 321,5 & 13,53 \\
\hline \multicolumn{5}{|c|}{ ATA2 } \\
\hline TSS & 342 & 50 & 6,84 & 5,17 \\
\hline BOD & 30 & 3 & 10 & 6 \\
\hline $\mathrm{pH}$ & 6,9 & $6-9$ & 0,4 & 0,4 \\
\hline Amonia & 5,78 & $\begin{array}{c}\leq \\
0,02\end{array}$ & 289 & 13,30 \\
\hline
\end{tabular}

Tabel 8. Rekapan status mutu air

\begin{tabular}{lccccc}
\hline No. & Lokasi & $\begin{array}{c}\text { Nilai Ci/Li } \\
\text { Rata-rata }\end{array}$ & $\begin{array}{c}\text { Nilai Ci/Li } \\
\text { Maksimum }\end{array}$ & Indeks Pencemaran & Status Mutu Air \\
\hline 1. & AP1 & 0,52 & 1,52 & 1,13 & Cemar Ringan \\
\hline 2. & AP2 & 0,67 & 2,02 & 1,50 & Cemar Ringan \\
\hline 3. & AP3 & 0,61 & 1,57 & 1,19 & Cemar Ringan \\
\hline 4. & APRF1 & 4,21 & 10,29 & 7,86 & Cemar Sedang \\
\hline 5. & APRF2 & 3,65 & 8,52 & 6,55 & Cemar Sedang \\
\hline 6. & SP1 & 2,43 & 7,87 & 5,82 & Cemar Sedang \\
\hline 7. & SP2 & 1,82 & 6,97 & 5,09 & Cemar Sedang \\
\hline 8. & ATK1 & 5,15 & 13,12 & 9,96 & Cemar Sedang \\
\hline 9. & ATK2 & 5,30 & 13 & 9,93 & Cemar Sedang \\
\hline
\end{tabular}




\begin{tabular}{lccccc}
\hline 10. & ATA1 & 5,88 & 13,53 & 10,43 & Cemar Berat \\
\hline 11. & ATA2 & 6,22 & 13,30 & 10,38 & Cemar Berat \\
\hline & Dari hasil rekapan Status Mutu Air & Fauzi Y, Widyastuti YE, Satyawibawa I, Paeru \\
pada Tabel 8, kondisi kualitas air dapat & RH. 2012. Kelapa Sawit. Jakarta \\
dikategorikan sebagai cemar ringan hingga & (ID): Penebar Swadaya.
\end{tabular}
cemar berat dengan nilai Indeks Pencemaran antara $1-10,43$. Peningkatan Status Mutu Air dari cemar ringan (nilai Pij 1,0-5,0) menjadi cemar berat (nilai PIj 5,0 - 10,0) terjadi pada titik ATA1 dan ATA2. Indeks pencemaran tertinggi terjadi pada ATA1 sebesar 10,43. Tingginya nilai Pij didominasi oleh besarnya nilai BOD pada kedua titik.

\section{PENUTUP}

\section{Kesimpulan}

Berdasarkan hasil penelitian dapat diambil kesimpulan bahwa kualitas LCPKS yang dihasilkan dari kolam pematangan atau kolam kontak sudah memenuhi baku mutu dan aman diaplikasikan ke lahan untuk meningkatkan kesuburan tanah dan membantu pertumbuhan tanaman kelapa sawit. Pengaruh LCPKS yang paling berdampak pada lingkungan adalah pada air tanah dengan status mutu air cemar berat dibandingkan air permukaan dengan status mutu air cemar sedang.

\section{DAFTAR PUSTAKA}

Azwir. 2006. Analisa Pencemaran Air Sungai Tapung Kiri Oleh Limbah Pabrik Kelapa Sawit PT. Peputra Masterindo Di Kabupaten Kampar. Universitas Diponegoro. Semarang.

Budianta.D.2004. Evaluasi pemanfaatan limbah cair kelapa sawit terhadap ketersediaan hara dan produksi tandan buah segar kelapa sawit. J tanah trop 10(1) : 27-32

Direktorat Jenderal Perkebunan. 2015. Statistik Perkebunan Indonesia 20142016 Kelapa Sawit. Jakarta (ID):Direktorat Jenderal Perkebunan.

Ditjen PPHP. 2006. Pedoman Pengelolaan Limbah Industri Kelapa Sawit. Subdit Pengelolaan Lingkungan. Departemen Pertanian. Jakarta

Fardiaz, S.1992. Polusi Air dan udara. Kanisius. Yogjakarta.

Hartley CWS. 2004. Environmental impact of oil palm plantations in Malaysia. Palm Oil Research Institute of Malaysia (PORIM). Occasional Paper. 33:127.

Ibe IJ, Oblige JN, Orji Jc, Nwanze PL, Ibejisika C, Okechi BN. 2014. Effects of palm oil mill effluent (POME) on soil bacteria and enzymes at different season. Int. J. Curr Microbial. App. Sci. 3(10): 928-934.

Indarti, D., dkk. 2014. Outlook Komoditi Kelapa Sawit.Jakarta: Pusat Data Dan Sistem Informasi Pertanian.

Kresnarini HI. 2011. Kampanye negatif kelapa sawit Indonesia Edisi Juni. Warta Ekspor. 1-19.

Keputusan Menteri Lingkungan Hidup No. 28 Tahun 2003 tentang Pedoman Teknis Pengkajian Pemanfaatan Air Limbah Dari Industri Minyak Sawit Pada Tanah di Perkebunan Kelapa Sawit.

Keputusan Menteri Negara LingkunganHidup No. 115 Tahun 2003 TentangPedomanPenentuan Status Mutu Air

Pemerintah Republik Indonesia. 2004. Undang-Undang Republik Indonesia Nomor 32 Tahun 2004 tentang Perlindungan dan Pengelolaan Lingkungan Hidup. Jakarta (ID):Sekretariat Negara.

Peraturan Pemerintah Republik Indonesia Nomor 82 Tahun 2001. Tentang Pengelolaan Air dan Pengendalian Pencemaran Air.

Rahayu AS, Karsiwulan D, Yuwono H,Trisnawati I, Mulyasari S, 
Rahardjo S, Hokermin S, Paramita V. 2014. Konversi POME menjadi biogas. Winrock International. 1-96.

Risza S. 1994. Kelapa Sawit Upaya Peningkatan Produktivitas. Yogyakarta(ID): Kansius.

Sugiharto. 1987. Dasar-dasar Pengelolaan Air Limbah. Jakarta (ID): Penerbit Universitas Indonesia (UI-Press). 190 hal.

Sembiring JV, Nelvia, Yulia AE. 2015. Pertumbuhan bibit kelapa sawit (Elaeis guineensis Jacq.) di pembibitan utama pada medium sup soil ultisol yang diberi asam umat dan kompos tandan kosong kelapa sawit. Jurnal Agroteknologi. 6(1): 25-32.

Suyatno, R. 1994. Kelapa Sawit: Upaya Meningkatkan Produktivitas. Kanisius. Yogyakarta. Hal 109-115.

SNI 06-6989.3-2004 tentang Air dan Air Limbah- Bagian 3: Cara Uji Padatan Tersuspensi Total (Total Suspended Solid, TSS) Secara Gravitimetri.

SNI 6989.59:2008 tentang Air dan Air Limbah - Bagian 59: Metoda Pengambilan Contoh Air Limbah.

SNI 6989.57:2008 tentang Air dan Air Limbah - Bagian 57: Metoda Pengambilan Air dan Air Limbah

SNI 6989.72:2004 tentang Air dan Air Limbah - Bagian 72: Cara uji Kebutuhan Oksigen Biokimia (BOD)

SNI06-6989.15-2004 tentang Air dan Air Limbah- Bagian 15: Cara uji Kebutuhan Oksigen Kimiawi (KOK) refluks terbuka dengan refluks terbuka secara spektrofotometri

SNI 06-6989.10-2004 tentang Air dan Air Limbah- Bagian 10: Cara uji Minyak dan Lemak secara Gravimetri
SNI 06-6989.11-2004 tentang Air dan Air Limbah- Bagian 11: Cara uji derajat keasaman $(\mathrm{pH})$ dengan menggunakan alat $\mathrm{pH}$ meter

SNI 06-6989.27-2005 tentang Air dan Air Limbah- Bagian 27: Cara uji padatan terlarut total secara Gravimetri

SNI 06-6989.25-2005 tentang Air dan Air Limbah- Bagian 25: Cara uji kekeruhan dengan Nefelometer

SNI 06-6989.14-2004 tentang Air dan Air Limbah- Bagian 14: Cara uji oksigen terlarut secara yodometri (modifikasiazida)

SNI 6989.79:2011 tentang Air dan air limbah - Bagian 79: Cara uji nitrat $\left(\mathrm{NO}_{3}^{-}-\right.$ $\mathrm{N})$ dengan spektrofotometer UVvisibel secara reduksi kadmium.

Orji MU, Nwokolo SO, Okoli I. 2006. Effects of palm oil mill effluent on soil microflora. Nigerian Journal of Biology. 20(2): 1026-1031.

Roslan AM, Hassan MA, Aziz SA, Yee PL. 2009. Effect of palm oil mill effluent supplementation on cellulase production krom Ice straw Bay localtunggal isolates. International Journal of Agriculture Research. 4: 185-192.

Virgianti H, Marsudi, Yusuf W. 2014. Pengaruh Land Application Terhadap Kualitas Air Tanah dan Air Permukaan di Kawasan PT.MSIP Bengkayang. Jurnal Universitas Tanjung Pura Pontianak.

Wahyudi H, Kasry A, Purwaningsih IS. 2011. Pemanfaatan limbah cair pabrik kelapa sawit untuk memenuhi kebutuhan unsur hara dalam budidaya tanaman jagung (Zea mays L.). Jurnal Ilmu Lingkungan. 5(2):94-102. 